\title{
ANTRIAN GERBANG KELUAR PARKIR DI UNIVERSITAS JENDERAL ACHMAD YANI CIMAHI
}

\author{
Antono Damayanto \\ Fakultas Teknik \\ Universitas Jenderal Achmad Yani \\ Jln. Ters. Jend. Sudirman, Cimahi \\ antono@ymail.com \\ Fernanda Virgiawan \\ Fakultas Teknik \\ Universitas Jenderal Achmad Yani \\ Jln. Ters. Jend. Sudirman, Cimahi \\ andavirgiawan@gmail.com
}

\author{
Prima Sukma Juana \\ Fakultas Teknik \\ Universitas Jenderal Achmad Yani \\ Jln. Ters. Jend. Sudirman, Cimahi \\ prima.s.yuana@ymail.com \\ Yogi Pratama \\ Fakultas Teknik \\ Universitas Jenderal Achmad Yani \\ Jln. Ters. Jend. Sudirman, Cimahi \\ yogipratama1408@yahoo.com
}

\begin{abstract}
The number of vehicles at Jenderal Achmad Yani University continues to increase, thus requiring increased parking security on campus. For this reason, Jenderal Achmad Yani University implemented a paid parking gate system, but this turned out to have an impact on the emergence of a long vehicle queue at the parking exit gate. This study aims to find a solution to minimize the length of the queue at the parking gate. In this study two alternatives are proposed, namely adding ticket booths (Alternative 1) or improving service time by using an automatic card system (Alternative 2). The results obtained show that for the next 5 years, Alternative 1 needs to add 1 ticket booth and Alternative 2 does not need to add ticket booth. For the next 10 years, Alternative 1 needs to add 1 more ticket booth in 2027, while Alternative 2 requires the addition of 1 ticket booth in 2026.
\end{abstract}

Keywords: parking, queue, service time, automatic card system

\begin{abstract}
Abstrak
Jumlah kendaraan di Universitas Jenderal Achmad Yani meningkat terus, sehingga memerlukan peningkatan keamanan parkir di kampus. Dengan alasan itu, Universitas Jenderal Achmad Yani menerapkan sistem gerbang parkir berbayar, tetapi hal ini ternyata berdampak pada timbulnya antrian kendaraan yang panjang di gerbang keluar parkir. Tujuan penelitian adalah mencari solusi untuk meminimalkan panjang antrian di gerbang keluar parkir. Pada studi ini diusulkan 2 alternatif, yaitu menambah gardu (Alternatif 1) atau memperbaiki waktu pelayanan dengan menggunakan sistem kartu otomatis (Alternatif 2). Hasil yang didapat menunjukkan bahwa untuk 5 tahun mendatang Alternatif 1 perlu menambah 1 gardu dan Alternatif 2 tidak perlu menambah gardu. Untuk 10 tahun mendatang, Alternatif 1 perlu menambah 1 gardu lagi pada tahun 2027, sedangkan Alternatif 2 membutuhkan penambahan 1 gardu pada tahun 2026.
\end{abstract}

Kata-kata kunci: parkir, antrian, waktu pelayanan, sistem kartu otomatis

\section{PENDAHULUAN}

Universitas Jenderal Achmad Yani (Unjani) merupakan salah satu perguruan tinggi swasta yang hingga saat ini terus berkembang. Hal ini terlihat dengan bertambahnya jumlah mahasiswa dan dosen serta staf pendukung di Unjani. Perkembangan Unjani tersebut tentu harus didukung dengan berbagai sarana dan prasarana yang memadai. Dampak penambahan jumlah mahasiswa, dosen, dan staf adalah meningkatnya jumlah kendaraan pribadi, terutama 
mobil dan motor, di lingkungan kampus. Salah satu aspek penting terkait hal ini adalah keamanan bagi parkir kendaraan, karena dalam beberapa tahun terakhir terdapat kendaraan, khususnya motor, yang hilang, padahal berada di area kampus.

Untuk mengatasi hal tersebut, sejak 2 tahun lalu, Unjani Kampus Cimahi bekerja sama dengan Parking Security menerapkan parkir dengan menggunakan sistem berbayar, yaitu memasang peralatan pada gerbang masuk dan gerbang keluar kampus. Dengan sistem berbayar, pengemudi mengambil karcis pada saat masuk dan mengembalikan karcis pada saat keluar. Mahasiswa, khususnya pengguna motor, dan dosen serta karyawan masingmasing mendapat 1 kartu parkir untuk keluar masuk kampus, atau dapat dikatakan mendapat fasilitas parkir gratis, yang bagi mahasiswa sudah termasuk dalam biaya SPP. Pada saat ini, karena lebih dari $95 \%$ kendaraan termasuk dalam golongan yang mendapat fasilitas parkir, semua kendaraan masih tidak membayar atau gratis.

Manfaat utama pemasangan gardu parkir sistem berbayar pada gerbang kampus Unjani Cimahi adalah meningkatkan faktor keamanan kendaraan di area kampus. Pada sisi lain, ternyata sering terjadi antrian yang signifikan, terutama pada gerbang keluar utama parkir Unjani Cimahi. Karena itu, perlu dilakukan evaluasi terhadap kondisi gerbang keluar utama tersebut, yang selanjutnya disebut gerbang keluar parkir.

Pada saat ini sering terjadi antrian yang panjang pada gerbang keluar parkir Unjani, khususnya pada jam sibuk. Hal ini mungkin terjadi akibat jumlah gardu parkir yang beroperasi tidak disesuaikan dengan volume kendaraan yang keluar, sehingga terjadi antrian yang panjang di gerbang parkir depan untuk keluar kampus Unjani Cimahi. Karena itu, perlu diupayakan untuk mengurai atau mengurangi panjang antrian tersebut, terutama pada jam sibuk.

Tujuan penelitian ini adalah menganalisis panjang antrian kendaraan pada gerbang keluar kampus Unjani Cimahi serta mencari solusi untuk mengurangi panjang antrian dan meningkatkan pelayanan dengan melakukan evaluasi intensitas lalu lintas pada gerbang tersebut. Jenis kendaraan yang menjadi fokus penelitian ini adalah mobil dan motor, karena kedua jenis kendaraan ini merupaan jenis kendaraan yang dominan parkir di kampus Unjani. Selain itu, gerbang parkir yang ditinjau adalah gerbang keluar parkir utama, karena pada gerbang ini terjadi antrian panjang pada saat jam puncak.

\section{METODOLOGI PENELITIAN}

Penelitian ini diharapkan dapat berjalan dengan baik dan memberi hasil sesuai dengan yang diharapkan. Untuk itu, dibuat suatu bagan alir penelitian, seperti yang ditunjukkan pada Gambar 1.

\section{Gerbang Parkir}

Gerbang parkir merupakan perlengkapan suatu pelataran parkir, yaitu gerbang masuk tempat pengambilan karcis parkir dan gerbang keluar untuk pengembalian karcis parkir. Pada gerbang keluar diperiksa karcis parkir tersebut dan dikenakan biaya kepada pemarkir 
serta pembayaran. Tetapi pada gerbang keluar parkir Unjani hanya dilakukan pemeriksaan karcis parkir dan tidak dikenakan biaya.

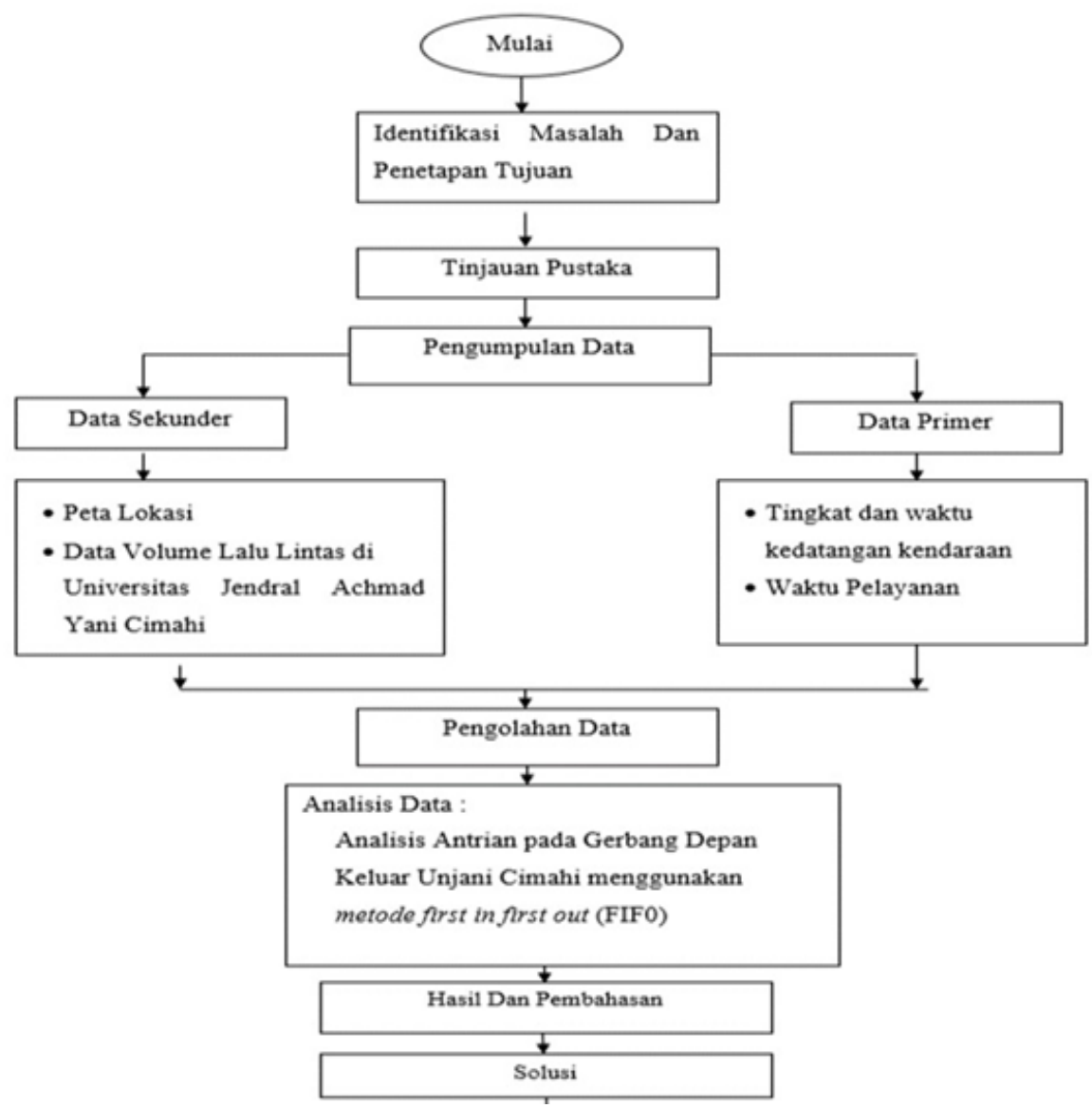

Gambar 1 Bagan Alir Metodologi Penelitian

Gerbang keluar parkir Unjani dapat dilihat pada Gambar 2. Gerbang ini meliputi: (1) Gardu masuk, pengendara kendaraan mengambil karcis parkir dengan menekan tombol yang sudah disediakan pada mesin karcis dan secara otomatis dilakukan pengambilan foto kendaraan tersebut dengan kamera; dan (2) Gardu keluar, pengendara mengembalikan karcis parkir dan petugas memeriksa kesesuaian karcis parkir dengan kendaraan.
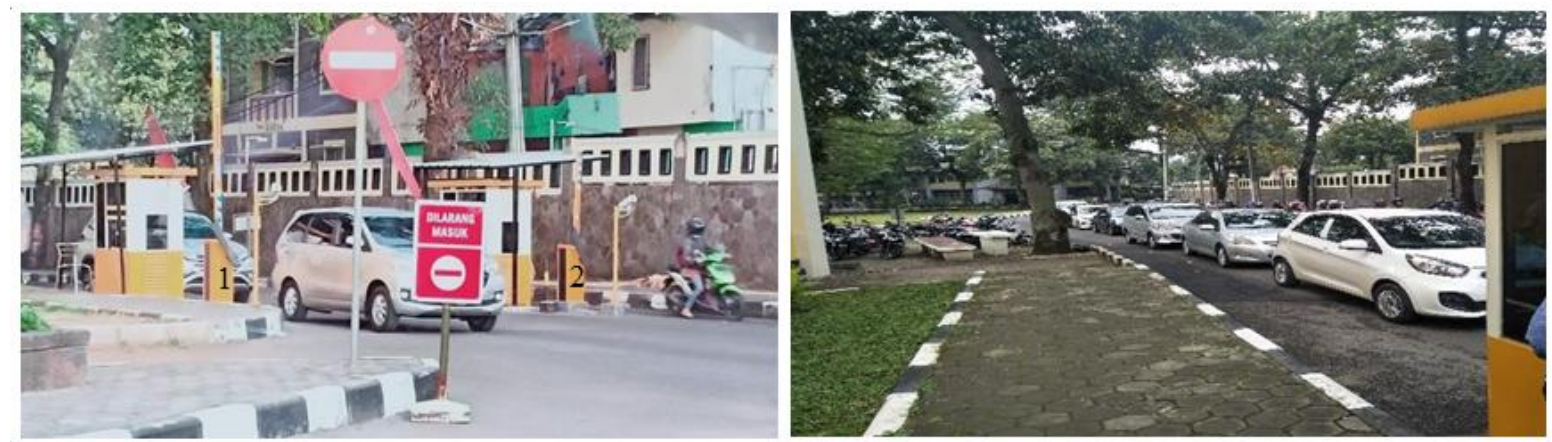

Gambar 2 Gerbang Keluar Parkir Unjani (2 Gardu) 


\section{Antrian}

Antrian yang panjang pada suatu gerbang parkir, pada umumnya terjadi karena adanya tingkat kedatangan (flow rate) yang tidak seimbang dengan tingkat pelayanan (service rate) di fasilitas pelayanan (Morlok, 1995; Taha, 2007). Berdasarkan pendekatan bahwa satuan waktu per unit pelayanan adalah tetap, maka lama waktu yang diperlukan kendaraan datang setelah kendaraan pertama yang masuk sistem pelayanan, merupakan lama waktu kumulatif. Dengan demikian, waktu terlama akan dialami oleh kendaraan yang datang paling akhir, selama disiplin antrian menggunakan pendekatan FIFO (first in first out). Hal ini akan dialami oleh setiap kendaraan yang datang menuju sistem antrian atau pintu pelayanan (Kakiay, 2004).

Tingkat kedatangan $(\lambda)$ adalah jumlah kendaraan atau manusia yang bergerak menuju satu atau beberapa tempat pelayanan dalam satu satuan waktu tertentu, yang umumnya dinyatakan dalam satuan kendaraan/jam atau orang/menit (Tamin, 2003). Probabilitas terjadinya $\mathrm{n}$ kedatangan dalam waktu $\mathrm{T}$ ditentukan sebagai berikut:

$$
\mathrm{P}(\mathrm{n}, \mathrm{T})=\frac{e^{-\lambda \mathrm{T}}(\lambda \mathrm{T})^{\mathrm{n}}}{\mathrm{n} !} \mathrm{n}=0,1,2, \ldots
$$

dengan:

$\lambda \quad=$ rata-rata kedatangan kendaraan per satuan waktu;

$\mathrm{T} \quad=$ periode waktu;

$\mathrm{N} \quad=$ jumlah kedatangan kendaraan dalam waktu $\mathrm{T}$; dan

$\mathrm{P}(\mathrm{n}, \mathrm{T})=$ probabilitas $\mathrm{n}$ kedatangan kendaraan dalam waktu $\mathrm{T}$.

\section{Komponen Antrian}

\section{Tingkat Kedatangan $(\lambda)$}

Tingkat kedatangan $(\lambda)$ adalah jumlah kendaraan atau manusia yang bergerak menuju satu atau beberapa tempat pelayanan dalam satu satuan waktu tertentu, yag dapat dinyatakan dalam satuan kendaraan/jam atau orang/menit. Setiap masalah antrian melibatkan kedatangan, misalnya orang, mobil, dan panggilan telepon untuk dilayani.

\section{Tingkat Pelayanan $(\mu)$}

Tingkat pelayanan $(\mu)$ adalah jumlah kendaraan atau manusia yang dapat dilayani oleh satu tempat pelayanan dalam satu satuan waktu tertentu. Tingkat pelayanan biasa dinyatakan dalam satuan kendaraan/jam atau orang/menit. Selain tingkat pelayanan, juga dikenal waktu pelayanan (WP) yang dapat didefinisikan sebagai waktu yang dibutuhkan oleh satu tempat pelayanan untuk dapat melayani satu kendaraan atau satu orang, yang biasa dinyatakan dalam satuan detik/kendaraan atau menit/orang.

$$
W P=\frac{1}{\mu}
$$


Selain itu, dikenal juga nisbah antara tingkat kedatangan $(\lambda)$ dengan tingkat pelayanan $(\mu)$, yang diberi notasi $\rho$. Nilai nisbah tersebut harus lebih kecil daripada 1 .

$$
\rho=\frac{\lambda}{\mu}<1
$$

Jika nilai $\rho$ bernilai lebih besar daripada 1 , hal ini berarti bahwa tingkat kedatangan lebih besar dari tingkat pelayanan. Jika hal ini terjadi, dapat dipastikan akan terjadi antrian yang akan selalu bertambah panjang.

\section{Disiplin Antrian}

Disiplin antrian adalah tentang tata cara kendaraan atau manusia mengantri. Beberapa jenis disiplin antrian yang sering digunakan dalam bidang transportasi atau arus lalu lintas adalah FIFO (First In First Out), FILO (First In Last Out), dan FVFS (First Vacant First Served). Disiplin antrian FIFO sangat sering digunakan di bidang transportasi ketika orang dan/atau kendaraan yang pertama tiba di suatu tempat pelayanan akan dilayani pertama (Tamin, 2003; Jotin dan Kent, 2003). Pada penelitian ini digunakan metode FIFO.
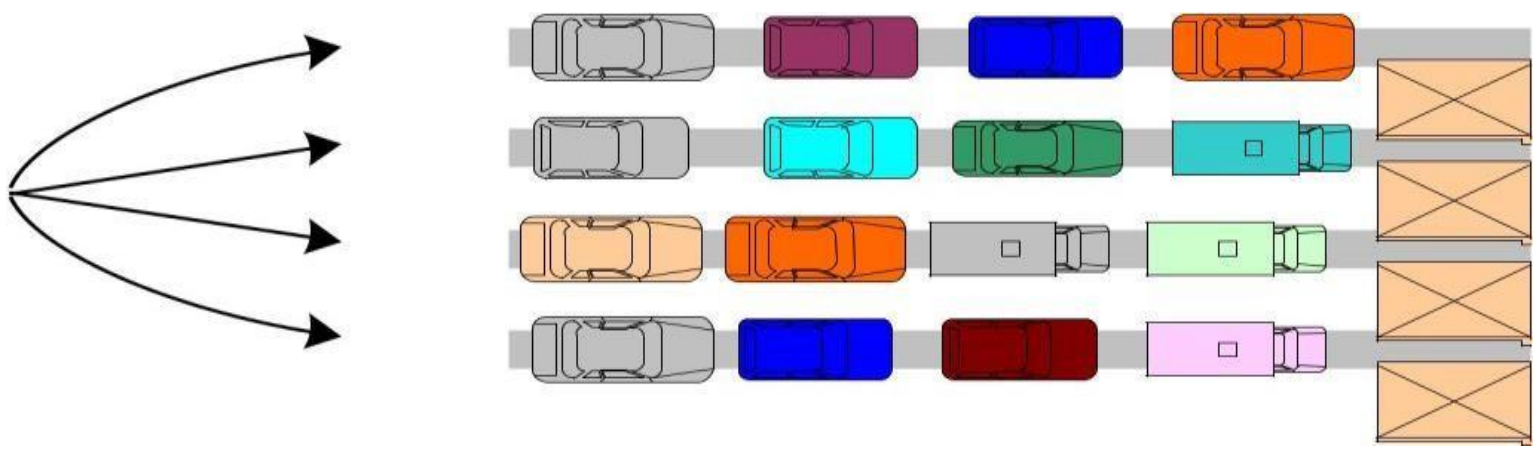

Gambar 3 Antrian Kendaraan pada Pintu Gerbang Parkir dengan Metode FIFO

Persamaan untuk menghitung n, q, d, dan w untuk disiplin antrian FIFO adalah:

$$
\begin{aligned}
& n=\frac{\lambda}{\mu-\lambda}=\frac{\rho}{1-\rho} \\
& q=\frac{\lambda^{2}}{\mu(\mu-\lambda)}=\frac{\rho^{2}}{1-\rho} \\
& d=\frac{1}{(\mu-\lambda)} \\
& w=\frac{1}{\mu(\mu-\lambda)}=d \frac{1}{\mu}
\end{aligned}
$$


dengan:

$\mathrm{n}=$ jumlah kendaraan atau orang dalam sistem (kendaraan per satuan waktu);

$\mathrm{q}=$ jumlah kendaraan atau orang dalam antrian (kendaraan per satuan waktu);

$\mathrm{d}=$ waktu kendaraan atau dalam sistem (kendaraan per satuan waktu); dan

$\mathrm{w}=$ waktu kendaraan atau dalam antrian (kendaraan per satuan waktu).

\section{PEMBAHASAN}

\section{Lokasi yang Ditinjau}

Lokasi yang ditinjau adalah gerbang parkir keluar Universitas Jenderal Achmad Yani di Cimahi. Pada gerbang keluar parkir ini, terdapat 2 buah pintu karcis. Satu pintu melayani motor dan satu pintu melayani mobil. Lokasi penelitian dapat dilihat pada Gambar 4.

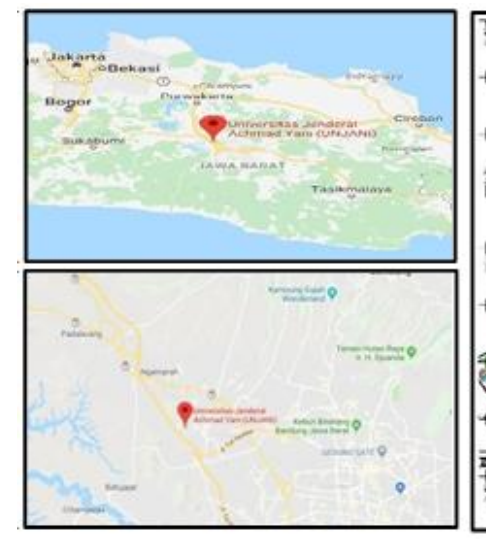

Gambar 4 Lokasi Penelitian

\section{Karakteristik Kendaraan}

Berdasarkan hasil survei, mobil banyak digunakan oleh para dosen. Sedangkan pengguna motor adalah $40 \%$ adalah mahasiswa dan 50\% adalah staf Unjani. Proporsi pengguna masing-masing jenis kendaraan dapat dilihat pada Gambar 5.
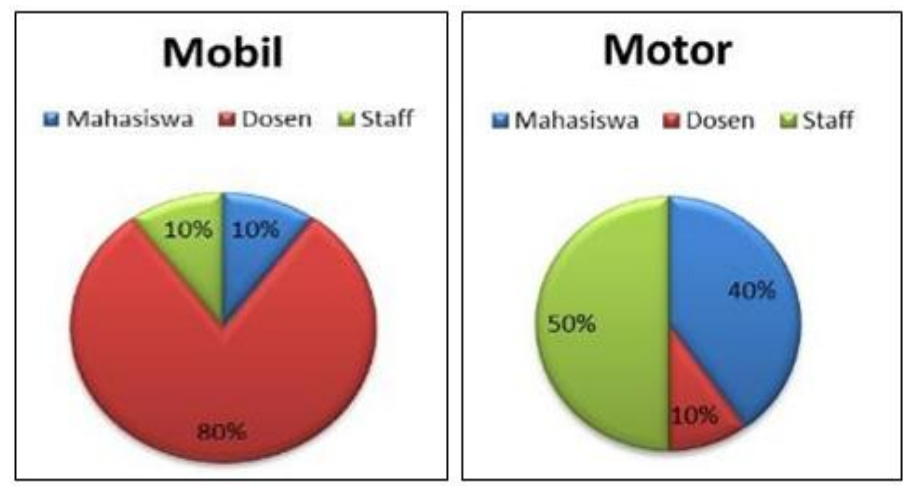

Gambar 5 Persentase Pengguna Kendaraan di Unjani Cimahi 


\section{Intensitas Gerbang Keluar Parkir Unjani Saat Ini}

Pada saat ini pelayanan pintu keluar parkir Unjani dilayani secara manual. Analisis intensitas yang dilakukan untuk mengetahui kondisi eksisting gerbang keluar parkir. Berdasarkan hasil survei, panjang antrian pada jam sibuk di kedua pintu karcis adalah 40,95 m untuk mobil dan 54,7 m untuk motor. Hasil survei tingkat kedatangan menunjukkan bahwa arus pergerakan kendaraan terbesar $(\lambda)$ adalah 671 motor dan 110 mobil, sehingga total adalah 781 kendaraan/jam, yang terjadi pada jam pulang kerja, yaitu jam 16.00-17.00. Data waktu pelayanan rata-rata pada gerbang keluar parkir, dengan 2 pintu karcis, adalah 9,3 detik/kendaraan. Dengan data hasil survei tngkat kedatangan dan waktu pelayanan pada gerbang keluar parkir diperoleh intensitas lalu lintas, seperti yang terdapat pada Tabel 1. Nilai $\rho$ yang diperoleh lebih besar daripada 1, yang berarti pada saat ini di gerbang keluar parkir telah terjadi antrian kendaraan. Karena itu, perlu dilakukan solusi untuk masalah ini.

Tabel 1 Intensitas Gerbang Keluar Parkir Unjani pada Saat Ini

\begin{tabular}{ccccc}
\hline WP $($ detik $)$ & $\lambda$ (kendaraan) & $\mathrm{N}($ gardu $)$ & $\mu$ & $\rho$ \\
\hline 9,3 & 781 & 2 & 387,10 & 1,009 \\
\hline
\end{tabular}

\section{Usulan Solusi terhadap Kondisi Eksisting}

Solusi yang diusulkan pada prinsipnya adalah mengurangi peluang terjadinya antrian. Pada studi ini direncanakan untuk membuat 2 alternatif solusi.

Alternatif pertama adalah dengan menambah jumlah pintu karcis, menjadi 2 pintu untuk motor dan 1 pintu untuk mobil. Dengan demikian total gerbang keluar parkir menjadi 3 pintu. Dengan penambahan 1 pintu karcis, didapat hasil seperti yang terdapat pada Tabel 2 , dengan nilai $\rho$ lebih kecil daripada 1 , yang berarti tidak terjadi antrian kendaraan yang panjang.

Tabel 2 Intensitas Gerbang Keluar Parkir Unjani Penambahan Gardu

\begin{tabular}{ccccc}
\hline WP $($ detik $)$ & $\lambda$ (kendaraan) & $\mathrm{N}($ gardu $)$ & $\mu$ & $\rho$ \\
\hline 9,3 & 781 & 3 & 387,10 & 0,673 \\
\hline
\end{tabular}

Alternatif kedua adalah dengan meningkatkan waktu pelayanan dengan menggunakan alat scan kartu parkir atau kartu parkir otomatis. Berdasarkan survei di gardu keluar parkir sejenis, yang menggunakan sistem karcis otomatis, waktu pelayanan rata-rata adalah 6,7 detik/kendaraan. Hasil perhitungan yang menggunakan sistem ini disajikan pada Tabel 3. Sistem ini memberikan nilai $\rho$ lebih kecil daripada 1, yang berarti antrian kendaraan masih dapat dilayani dengan 2 pintu keluar, tetapi menggunakan kartu saat keluar.

Dengan sistem karcis otomatis pengendara wajib untuk berhati-hati terhadap penyimpanan kartu yang digunakan, karena pada prinsipnya tidak diperlukan penjaga gardu. Sedangkan pada sistem manual, penjaga gardu karcis dapat mengecek terlebih dahulu apakah pengendara dan kendaraan sesuai dengan data saat masuk, melalui kamera di layar monitor. Selain itu, terdapat permasalahan lain, yaitu pengendara yang masuk ke kampus Unjani bukan hanya sivitas akademika, tetapi ada masyarakat yang masuk atau melewati 
kampus, dan mereka tidak memiliki karcis otomatis, sehingga mereka harus mengambil karcis manual. Karena itu penerapan alternatif 2 ini masih memerlukan kajian lebih lanjut.

Pada studi ini juga dilakukan simulasi untuk beberapa nilai waktu pelayanan dengan beberapa skenario jumlah gardu karcis. Hasil perhitungan dengan menggunakan prinsip FIFO ditampilkan pada Tabel 4.

Tabel 3 Kinerja Gerbang Keluar Parkir Unjani Menggunakan Kartu Otomatis

\begin{tabular}{ccccc}
\hline WP $($ detik $)$ & $\lambda$ (kendaraan) & $\mathrm{N}($ gardu $)$ & $\mu$ & $\rho$ \\
\hline 6,7 & 781 & 2 & 537,31 & 0,726 \\
\hline
\end{tabular}

Tabel 4 Rekapitulasi Antrian FIFO pada Gardu Keluar

\begin{tabular}{|c|c|c|c|c|c|c|c|c|c|c|c|c|c|c|c|}
\hline & \multicolumn{3}{|c|}{$\mathrm{WP}=5$ Detik } & \multicolumn{3}{|c|}{$\mathrm{WP}=6$ Detik } & \multicolumn{3}{|c|}{ WP $=7$ Detik } & \multicolumn{3}{|c|}{$\mathrm{WP}=8$ Detik } & \multicolumn{3}{|c|}{$\mathrm{WP}=9$ Detik } \\
\hline & 2 & 3 & 4 & 2 & 3 & 4 & 2 & 3 & 4 & 2 & 3 & 4 & 2 & 3 & 4 \\
\hline $\mathrm{n}$ & 1,18 & 0,56 & 0,37 & 1,86 & 0,766 & 0,48 & 3,15 & 1,025 & 0,611 & 6,56 & 1,37 & 0,76 & 41,1 & 1,86 & 0,95 \\
\hline$q$ & 0,64 & 0,204 & 0,1 & 1,21 & 0,33 & 0,15 & 1,88 & 0,44 & 0,204 & 5,695 & 0,794 & 0,332 & 40,12 & 1,21 & 0,465 \\
\hline d & 10,92 & 7,83 & 6,86 & 17,18 & 10,59 & 8,89 & 29,08 & 14,17 & 11,28 & 60,504 & 18,98 & 14,131 & 378,947 & 25,77 & 17,58 \\
\hline w & 5,925 & 2,831 & 1,86 & 11,183 & 4,59 & 2,89 & 22,081 & 7,17 & 4,283 & 52,504 & 10,98 & 6,131 & 369,94 & 16,77 & 8,58 \\
\hline
\end{tabular}

dengan:

$\mathrm{n} \quad=$ rata-rata jumlah kendaraan dalam sistem (kendaraan);

$\mathrm{q} \quad=$ rata-rata jumlah kendaraan dalam antrian (kendaraan);

$\mathrm{d} \quad=$ waktu rata-rata yang dipakai dalam sistem (detik);

$\mathrm{w} \quad=$ waktu rata-rata yang dipakai dalam antrian (detik); dan

2, 3, 4 = jumlah gardu karcis parkir.

\section{Analisis Intensitas Gerbang Keluar Parkir Unjani dalam 5 Tahun Mendatang}

Pada penelitian ini, digunakan nilai pertumbuhan rata-rata untuk mobil sebesar $4,10 \%$ dan untuk motor sebesar 4,56\%. Berdasarkan asumsi pertumbuhan kendaraan tersebut adalah konstan, dilakukan prediksi jumlah kendaraan di masa yang akan datang, seperti yang terdapat pada Tabel 5.

Tabel 5 Prediksi Jumlah Kendaraan

\begin{tabular}{cccc}
\hline Tahun & Motor & Mobil & Jumlah \\
\hline 2020 & 734 & 120 & 854 \\
2021 & 767 & 126 & 893 \\
2022 & 802 & 131 & 934 \\
2023 & 839 & 137 & 967 \\
2024 & 877 & 144 & 1021 \\
\hline
\end{tabular}

Dengan penambahan gardu serta menggunakan prediksi jumlah kendaraan di kampus Unjani Cimahi dalam 5 tahun mendatang dan tingkat pelayanan seperti yang ada saat ini, yaitu 9,3 detik/kendaraan, dihitung intensitas gerbang keluar parkir. Hasilnya dapat dilihat pada Tabel 6. Dalam 5 tahun mendatang (hingga tahun 2024), parkir keluar kampus Unjani dapat dilayani dengan 3 gardu, karena nilai $\rho$ yang diperoleh masih lebih kecil daripada 1. 
Tabel 6 Intensitas Gerbang Keluar Parkir Unjani 5 Tahun dengan Penambahan Gardu

\begin{tabular}{cccccc}
\hline Tahun & WP $($ detik $)$ & $\lambda$ (kendaraan) & N $($ gardu $)$ & $\mu$ & $\rho$ \\
\hline 2020 & 9,3 & 854 & 3 & 387,10 & 0,735 \\
2021 & 9,3 & 893 & 3 & 387,10 & 0,769 \\
2022 & 9,3 & 934 & 3 & 387,10 & 0,840 \\
2023 & 9,3 & 976 & 3 & 387,10 & 0,841 \\
2024 & 9,3 & 1021 & 3 & 387,10 & 0,879 \\
\hline
\end{tabular}

Bila digunakan sistem karcis otomatis, dengan menggunakan prediksi jumlah kendaraan di kampus Unjani untuk 5 tahun mendatang dan tingkat pelayanan diperbaiki menjadi 6,7 detik/kendaraan, didapat intensitas gerbang keluar parkir Unjani, seperti yang terdapat pada Tabel 7. Dengan perbaikan waktu pelayanan menjadi lebih cepat, yaitu 6,7 detik/kendaraan, ternyata 2 gardu masih dapat melayani sampai dengan 5 tahun mendatang, yaitu tahun 2024.

Tabel 7 Intensitas Gerbang Keluar Parkir Unjani dengan Perbaikan Waktu Pelayanan

\begin{tabular}{cccccc}
\hline Tahun & WP $($ detik $)$ & $\lambda$ (kendaraan) & $\mathrm{N}($ gardu $)$ & $\mu$ & $\rho$ \\
\hline 2020 & 6,7 & 854 & 2 & 537,31 & 0,795 \\
2021 & 6,7 & 893 & 2 & 537,31 & 0,831 \\
2022 & 6,7 & 934 & 2 & 537,31 & 0,869 \\
2023 & 6,7 & 976 & 2 & 537,31 & 0,908 \\
2024 & 6,7 & 1021 & 2 & 537,31 & 0,950 \\
\hline
\end{tabular}

\section{Analisis Intensitas Gerbang Keluar Parkir Unjani dalam 10 Tahun Mendatang}

Evaluasi lebih lanjut adalah untuk kondisi 5 tahun sampai dengan 10 tahun mendatang. Untuk Alternatif 1, yaitu dengan 3 gardu tanpa percepatan waktu pelayanan, sampai dengan tahun 2026 belum memerlukan penambahan gardu. Tetapi pada tahun 2027 diperlukan penambahan 1 gardu karena nilai $\rho$ yang diperoleh sudah lebih besar daripada 1, yaitu 1,005, sehingga total menjadi 4 gardu. Sedangkan untuk Alternatif 2, yaitu dilakukan percepatan waktu pelayanan sejak tahun eksisting, maka 2 gardu dapat melayani sampai dengan tahun 2025. Pada tahun 2026 diperlukan penambahan 1 gardu karena diprediksi pada tahun 2026 sudah terjadi antrian yang panjang, dengan nilai $\rho$ lebih besar daripada 1, yaitu 1,038, sehingga jumlah gardu yang diperlukan adalah 3 gardu.

\section{KESIMPULAN}

Unjani menerapkan sistem parkir berbayar sejak 2 tahun lalu dengan tujuan utama meningkatkan keamanan parkir di dalam kampus Unjani Cimahi. Gerbang keluar parkir Unjani Cimahi yang beroperasi pada saat ini terdiri atas 2 gardu pemeriksaan karcis, 1 untuk mobil dan 1 lagi untuk motor.

Untuk kondisi saat ini, berdasarkan hasil survei gerbang keluar parkir, tingkat kedatangan kendaraan pada jam puncak adalah 789 kendaraan/jam, yang terdiri atas motor sebanyak: 671 kendaraan dan mobil 110 kendaraan, dan terjadi pada jam pulang kerja, yaitu 
jam 16.00-17.00. Berdasarkan waktu pelayanan rata-rata sebesar 9,3 detik/kendaraan, diperoleh tingkat pelayanan sebesar 387,09 dan $\rho$ sebesar 1,009, yang berarti telah terjadi antrian yang panjang.

Usulan alternatif perbaikan intensitas lalu lintas kendaraan untuk kondisi eksisting direncanakan dengan 2 skenario. Pertama adalah penambahan gardu dan kedua adalah memperbaiki waktu pelayanan dengan menggunakan karcis ototmatis (scan). Hasil analisis, untuk Alternatif 1 adalah diperlukannya penambahan 1 buah gardu karcis, sehingga menjadi 3 gardu. Sedangkan untuk Alternatif 2, ternyata 2 gardu masih cukup untuk melayani hingga 5 tahun mendatang. Akan tetapi jika alternatif 2 ini diterapkan, pengendara harus berhatihati dalam menyimpan kartu yang digunakan. Selain itu, diperlukan juga kajian lebih jauh terkait masyarakat yang masuk kampus dan menggunakan karcis manual.

Untuk 5 tahun mendatang, berdasarkan hasil prediksi jumlah kendaraan dan menggunakan Alternatif 1, jumlah 3 gardu karcis masih cukup. Sedangkan untuk Alternatif 2, hingga tahun 2024 jumlah 2 gardu masih cukup.

Untuk 10 tahun mendatang, Alternatif 1 membutuhkan penambahan 1 gardu pada tahun 2027, sehingga menjadi 4 gardu. Sedangkan untuk Alternatif 2, diperlukan penambahan 1 gardu pada tahun 2026, jumlah gardu total menjadi 3 gardu.

\section{DAFTAR PUSTAKA}

Jotin, C.K. dan Kent, B.L. 2003. Dasar-Dasar Rekayasa Transportasi (terjemahan) Jilid 1. Jakarta: Erlangga.

Kakiay, T.J. 2004. Dasar Teori Antrian. Yogyakarta: Penerbit Andi.

Morlok, E.K., 1995. Pengantar Teknik dan Perencanaan Transportasi (terjemahan). Jakarta: Erlangga.

Taha, H. 2007. Riset Operasi (terjemahan). Jilid 2 Edisi Kelima. Jakarta: Binarupa.

Tamin, O.Z. 2003. Perencanaan dan Pemodelan Transportasi. Edisi Satu. Bandung: Departemen Teknik Sipil, Institut Teknologi Bandung. 